\title{
Seasonal variations in the production and distribution of Zooplankton in Coringa back waters of Kakinada Bay.
}

\author{
Dr.P.Anil Kumar, Ph.D \\ Lecturer in Zoology, P.R.Government College(A),Kakinada - 533001
}

\begin{abstract}
Climatological changes in the coming decades most likely will alter compositions and abundances of zooplankton. What we need to rapidly and comprehensively assess polar, boreal, subtropical and tropical regions and communities is automated instrumentation with which longer time-series and frequent coverage are possible. Such long-time series could be obtained from an Ocean Observatory (Wiebe et.al. 1987). These field studies need to cover processes over scales from seconds to decades, especially to distinguish between natural variance and that created by climatological changes.
\end{abstract}

Key words: Zooplankton, Coringa,Mangroves, Biomass, Numerical abundance

\section{Introduction:}

Characterization of small-scale individual behavior,the vast majority of process studies on marine zooplankton in the ocean or in the laboratory have been on populations in assemblages and communities. No individual zooplankton organism has been studied over any extended period of time in the ocean or in a community like Coringa Estuary. Thus, the distribution and behavior of zooplankton at the level of the individual organism, and their importance to biological and chemical processes in the ocean or in actual study i.e Coringa are largely unknown.

\section{Materials and Methods :}

Monthly surface zooplankton samples were made out at the selected two stations in the Coringa river.Surface zooplankton samples were collected by employing a $120 \mu \mathrm{m}$ mesh sized net of $40 \mathrm{~cm}$ diameter. As soon as the net was hauled the contents in the cod end collector of the net were gently transferred in to a clean polyethylene container and fixed with $5 \%$ formaldehyde solution. In the laboratory biomass was measured by the displacement method (WICKSTEAD, 1965) and expressed as $\mathrm{ml}-\mathrm{m}^{-3}$. For the enumeration of Zooplankton aliquot method was employed (Wickstead, 1965), where the total sampled was sub sampled and 10 $\mathrm{ml}$. aliquot, was taken in to a petridish provided with a grid, and the major groups of zooplankton were enumerated according to the illustrations given by Wickstead (1965). Prior to the sub sampling larger forms like Hydromedusae, Siphonophores were separated from the sample and counted separately. Zooplankton numerical abundance was expressed as no $/ \mathrm{m}^{3}$

\section{Results :}

Monthly Variations In Zooplankton Composition At Station - I

\begin{tabular}{|c|c|c|c|c|c|c|c|c|c|}
\hline & Jan'10 & Feb & Mar & April & May & June & Mean & Min & Max \\
\hline $\begin{array}{l}\text { Biomass } \\
\left(\mathrm{ml} / \mathrm{m}^{-3}\right)\end{array}$ & 0.22 & 2.04 & 0.30 & 0.51 & 2.14 & 0.8 & 1.001 & 0.30 & 2.14 \\
\hline $\begin{array}{c}\text { Numerical } \\
\text { Abundance (no/ } \\
\left.\mathrm{m}^{3}\right)\end{array}$ & 11543 & 56430 & 20213 & 28322 & 41367 & 25578 & 30513 & $\begin{array}{c}1154 \\
3\end{array}$ & 56430 \\
\hline Copepods & $\begin{array}{r}9899 \\
(85.75) \\
\end{array}$ & $\begin{array}{c}37002 \\
(65.67) \\
\end{array}$ & $\begin{array}{c}10527 \\
(37.15) \\
\end{array}$ & $\begin{array}{c}10527 \\
(37.15) \\
\end{array}$ & $\begin{array}{r}25190 \\
(50.89) \\
\end{array}$ & $\begin{array}{c}15388 \\
(58.150 \\
\end{array}$ & 18,827 & 9899 & 37002 \\
\hline Decapod Larvae & $\begin{array}{c}852 \\
(7.38) \\
\end{array}$ & $\begin{array}{c}2880 \\
(5.11) \\
\end{array}$ & $\begin{array}{r}1995 \\
(9.86) \\
\end{array}$ & $\begin{array}{c}799 \\
(2.82) \\
\end{array}$ & $\begin{array}{c}2470 \\
(7.38) \\
\end{array}$ & $\begin{array}{r}2133 \\
(9.89) \\
\end{array}$ & 1854 & 799 & 2880 \\
\hline Chactognaths & -- & -- & -- & $\begin{array}{c}959 \\
(3.38) \\
\end{array}$ & $\begin{array}{c}812 \\
(1.160 \\
\end{array}$ & $\begin{array}{c}186 \\
(0.82) \\
\end{array}$ & 652 & 186 & 959 \\
\hline Luicifers & $\begin{array}{c}16 \\
(0 . \mathrm{B}) \\
\end{array}$ & $\begin{array}{c}29 \\
(0.65) \\
\end{array}$ & - & 194 & $\begin{array}{c}1610 \\
(3.89) \\
\end{array}$ & $\begin{array}{c}283 \\
(1.25) \\
\end{array}$ & 426 & 16 & 1610 \\
\hline Gastropod Veligers & $\begin{array}{c}252 \\
(218)\end{array}$ & $\begin{array}{c}10350 \\
(18.37)\end{array}$ & $\begin{array}{c}1332 \\
(6.58)\end{array}$ & $\begin{array}{c}12558 \\
(44.33) \\
\end{array}$ & $\begin{array}{c}5560 \\
(13.44)\end{array}$ & $\begin{array}{c}2686 \\
(11.89) \\
\end{array}$ & 5456 & 252 & 12588 \\
\hline Polychaete larvae & -- & $\begin{array}{c}833 \\
(1.47) \\
\end{array}$ & $\begin{array}{c}240 \\
(1.18)\end{array}$ & -- & $\begin{array}{c}167 \\
(0.40)\end{array}$ & $\begin{array}{c}121 \\
(0.54) \\
\end{array}$ & 340 & 121 & 833 \\
\hline Bivalve Veligers & $\begin{array}{c}330 \\
(2.85) \\
\end{array}$ & $\begin{array}{c}4897 \\
(8.69) \\
\end{array}$ & $\begin{array}{l}1280 \\
(8.69)\end{array}$ & $\begin{array}{l}2649 \\
(9.35)\end{array}$ & $\begin{array}{c}5322 \\
(12.86)\end{array}$ & $\begin{array}{c}1601 \\
(7.09)\end{array}$ & 2679 & 330 & 5322 \\
\hline
\end{tabular}


Seasonal variations in the production and distribution of Zooplankton in Coringa back waters of

\begin{tabular}{|c|c|c|c|c|c|c|c|c|c|}
\hline Appendicularians & $\begin{array}{c}67 \\
(0.58) \\
\end{array}$ & -- & -- & -- & -- & $\begin{array}{c}59 \\
(0.14)\end{array}$ & 63 & 59 & 67 \\
\hline Ostracods & -- & $\begin{array}{c}219 \\
(0.38) \\
\end{array}$ & $\begin{array}{c}128 \\
(0.63) \\
\end{array}$ & $\begin{array}{c}43 \\
(0.15) \\
\end{array}$ & $\begin{array}{c}178 \\
(0.43) \\
\end{array}$ & $\begin{array}{c}80 \\
(0.35) \\
\end{array}$ & 129. & 43 & 178 \\
\hline Cladocerens & $\begin{array}{c}95 \\
(082) \\
\end{array}$ & $\begin{array}{c}131 \\
(0.23) \\
\end{array}$ & $\begin{array}{c}165 \\
(0.820 \\
\end{array}$ & $\begin{array}{c}47 \\
(0.16) \\
\end{array}$ & -- & -- & 109 & 47 & 165 \\
\hline $\begin{array}{l}\text { Miscellaneous } \\
\text { groups }\end{array}$ & $(0.03)$ & $(0.050$ & $(0.04)$ & $(0.040$ & $(0.02)$ & $(0.02)$ & & & \\
\hline
\end{tabular}

Number in the Parentheses indicate percentage in total Zooplankton.

Station I:

Biomass: The zooplankton biomass at the station I varied between $0.30 \mathrm{ml} . \mathrm{m}^{-3}$ to a maximum of $2.14 \mathrm{ml} . \mathrm{m}^{-3}$ with a mean of $1.0 \mathrm{ml} . \mathrm{m}^{-3}$.

Numerical abundance: Zooplankton numerical abundance at the station I varied between 11543 no. $^{-3}$ to a maximum of 56430 no. $\mathrm{m}^{-3}$ with a mean of 30513 no. $\mathrm{m}^{-3}$

Copepods: Copepods constitute the bulk of the plankton at the present station the abundance of the copepods ranged from aminimum of 9899 no. $\mathrm{m}^{-3}$ to a maximum of 37002 no. $\mathrm{m}^{-3}$ with a mean of 18827 no. ${ }^{-3}$.

Decapod Larvae: The decapod larval abundance varied between 799 no. $\mathrm{m}^{-3}$ and 2880 no.m $^{-3}$ with a mean of 1854 no. $\mathrm{m}^{-3}$.

Chaetognaths: The abundance of the chaetognaths varied between 186 no. $\mathrm{m}^{-3}$ and 959 no. $\mathrm{m}^{-3}$ with a mean of 652 no.m $^{-3}$.

Lucifers: The abundance of the lucifers varied between 16 no. $^{-3}$ and 1610 no. $\mathrm{m}^{-3}$ with a mean of $426 \mathrm{no}^{-3} \mathrm{~m}^{-3}$.

Gastropod Veligers: The abundance of the gastropod veligers ranged from a minimum of $252 \mathrm{no}^{-3}$ to a maximum of 12588 no.m $^{-3}$ with a mean of 5456 no. $^{-3}$.

Polychaete larvae: The polychaete larval abundance varied between 121 no. $\mathrm{m}^{-3}$ and 12588 no. $\mathrm{m}^{-3}$ with a mean of 340 no.m . $^{-3}$.

Bivalve veligers: The bivalve veligers abundance varied between 330 no. $\mathrm{m}^{-3}$ and 5322 no. $^{-3}$ with a mean of 2679 no. $\mathrm{m}^{-3}$.

Appendicularians: Abundance of the appendicularians varied between 59 no. $\mathrm{m}^{-3}$ and 67 no. $\mathrm{m}^{-3}$ with a mean of 63 no.m $\mathrm{m}^{-3}$.

Ostracods: The abundance of Ostracods ranged between 43 no.m $\mathrm{m}^{-3}$ and 178 no. $\mathrm{m}^{-3}$ with a mean of 129 no.m $\mathrm{m}^{-3}$.

Cladocerns: Cladocern abundance varied between 47 no. $\mathrm{m}^{-3}$ and 165 no. $\mathrm{m}^{-3}$ with a mean of 109 no. $^{-3}$.

The miscellaneous groups includes hydromedusae, ctenophores, siphonophores and other larger planktonic groups.

\section{Discussion and Summary}

The numerical abundance and biomass of Zooplankton in the area during the study period showed two peaks of abundance one in January - February and another in May. Even though the hydrographical conditions were highly fluctuating, the numerical abundance and biomass of Zooplankton was considerably high and it showed seasonal climatic effects.

The results revealed that the mangrove areas support high zooplankton populations. The zooplankton population was mostly dominated by copepods ranging between $53 \%-83 \%$ of total populations. Estuarine environments exhibited wide range of fluctuations in physical and chemical factors in both time and space demanding considerable physiological and behavioral plasticity in the Organisms which colonize them. Estuaries are among the most productive ecosystems, largely as a result of allochthonous organic matter inputs from surrounding marshes, swamps and inflowing of rivers, as well as urban generated organic matter (Lay bourn - Parry et all, 1992).

Large scale conversion of mangrove areas for brackish water fish and shrimp ponds in the area ,and heavy petrochemical industries including fertilizer factories has not only rapidly depleted the valuable mangrove resources but also impaired the ecological balance in the estuarine ecosystem where mangroves are generally located. The present study is a baseline study, further studies throws light on the significance of Coringa river and the Coringa wild life sanctuary in the Kakinada Bay and Godavari estuarine environment complex.

\section{References}

[1]. Achuthankutty C.T, and George M.J. and Goswami S .C, 1977,. Larval regression of penaeid prawns in the estuaries of Goa. Proc. Symp. Warm water Zooplankton. UNESCO / NIO Spl. Pub 412-424.

[2]. Allan J.D., Kinsey T.G. and James J.L. 1976.Abundance and production of copepods in the Rhode river estuary of chespeake Bay .,Chespeake .Sci $17: 86-92$.

[3]. Antony MK, Panakala Rao. D and Sankaranarayana V.N. 1974.Studies on the monsoonal flow of the Mandovi estuary, Mahasagar, Bull. Nat. Inst. Oceanography 7 (1\&2) 69-72. 
[4]. APHA. 1971., Standard methods for the examination of water and waste water. Michel J.T. Arnold E-G, Hoak R.D. and Rand M.C. (eds) American Public Health Association (Pub) Washington, D.C. 13 Edn. 874 PP

[5]. Bhunia, A.B, and Choudhury A. 1982. Zooplankton distribution in the Sundaraban Mangroves., Mahasagar Bull. Nat. Inst. Oceanography $15: 247$.

[6]. Carrit DE and carpenter, J.H. 1966.,Composition and evaluation of currently employed modification of winkler's method for determining dissolved oxygen in Sea water, a NASCO Report. J. Mar. Res. 24: 296-318

[7]. Colebrook.J.M.1985.Continuous plankton records over winter and annual fluctuations in the abundance of zooplankton.Mar.Biol 84,261-265

[8]. P.Raminez Garcia,S.Nandini et.al,2002.seasonal Variations of zooplankton abundance in the freshwater reservoir Valle de Bravo,Hydrobiologia,2002,467,1-3,99-108

[9]. S.B.Hulyal and B.B.Kaliwat,2005:Water quality assessment of Almatti reservoir of Bijapur with special reference to zooplankton.Environmental Monitoring and Assessment.2008,139,1-3,p 299-306

[10]. Shanmugam, A, Kasinathn, R and Maruthamuthu S., 1986.,Bionass and composition of Zooplankton from pitchavaram mangroves, south east coast of India. Indian J. Mar. Sci - $15: 111-113$.

[11]. Singbal SYS. 1973,. Diurnal variations of some physico-chemical factors in the Zuari estuary of Goa. Indian J. Mar. Sci., 2 (2) 9093.

[12]. V.V.Nadtochy.2004.Seasonal dynamics of plankton in zones with different thermal structures of water off the southern Kuri islands, Russian Journal of Marine Biology.Vol.30,4 P.223-230

[13]. Wellershans, S. 1971 on the Hydrography of the Cochin back water, a south Indian estuary J. Mar. Biol. Ass. India. 13 (2) 487 495 .

[14]. Wickstead, J.H. 1965.An introduction to the study of tropical plankton, 1-160,Hutchinson's tropical Monographs, London.

[15]. Wiebe,P.H.Miller,C.B.Mc Gowan,J.A.Knox,R.A,1987.Long line series study of oceanic ecosystems.EOS 68.1178,1180-1183 